\title{
Schematic-Topological Modeling of the SOI CMOS Ring Oscillators for Sensor Microsystems on Chip
}

\author{
Vasyl Stefanyk Precarpathian National University, 57, Shevchenko st., Ivano-Frankivsk, 76018, Ukraine, \\ e-mail: mishanyakit@gmail.com
}

\begin{abstract}
The paper presents the results of research of frequency and energy characteristics of ring generators on the basis of siliconon-isolator of the CMOS transistor structures, depending on their circuit design and constructive and technological implementation, design and modeling of the schemes of the primary transformation of information from integral sensitive elements for sensor microsystems-on-crystal
\end{abstract}

Keywords: silicon-on-insulator; ring generator; sensitive element; sensor microsystem on the chip.

Article acted received 20.09.2018; accepted for publication 15.12.2018.

\section{Introduction}

One of the important elements of the Sensor Microsystems-on-chip (SMSoC) are ring oscillators which can be used as part of the registration schemes of primary information of changes in physical quantities from different types of sensor elements (SE), in particular, capacitive, resistive, light-sensitive, transistor type and others. In addition, the ring oscillator is an informative object for evaluating element base parameters with new and little-investigated technologies and can be the source of pulse signals in integrated circuits and sensor Microsystems-on-chip [1].

The analysis of existing microelectronic technologies shows widespread use of silicon-oninsulator (SOI) structures due to their superior properties regarding electrical characteristics, power consumption, resistance to external influences (high / low temperature, elevated levels of radiation, strong magnetic fields, etc.) are significantly better than those known in bulk silicon. In addition, the SOI-structures have significant advantages as a constructive material for the creation of new constructive elements, including both new threedimensional structures and the integration possibilities with sealed or unsealed microcavities under the surface of the silicon wafer [2]. This opens up additional possibilities for the creation of new integrated device structures and will expand the functionality of SMSoC, expand the scope of their application.

The article presents the results of the schematictopological modeling of the developed electric circuits, the topology of the ring oscillator on the basis of the
SOI-structures consisting of an odd number of inverters. Also, the frequency and energy characteristics of the ring oscillators are investigated depending on their circuit design, layouts, structural and technological implementation. The primary information registration schemes from integral sensitive elements for SMSoC are designed and simulated.

In ring oscillators modeling for SOI SMSoC $n$ - and $p$-channel MOS-transistors with topological dimensions $\mathrm{W}=10 \mu \mathrm{m}, \mathrm{L}=2 \mu \mathrm{m}$ and $\mathrm{W}=20 \mu \mathrm{m}, \mathrm{L}=2 \mu \mathrm{m}$, respectively. In all investigated circuits, the supply voltage range from $2.5 \mathrm{~V}$ to $5 \mathrm{~V}$ is used.

\section{Frequency characteristics modeling of ring oscillator cell}

The electric circuit, topology, and three-dimensional image of the SOI CMOS ring oscillator based on a matrix cell which contains five interconnected inverters are shown in Fig. 1 a, b, c

One of the factors influencing the frequency characteristics of ring oscillators is the thickness of the oxide under the gate, which determines the threshold voltage of the SOI CMOS-transistors. Results of computer simulation of the frequency dependence of the five-cascades ring oscillator from the thickness of the oxide for the scheme of Fig. 1 is shown in Fig. 2

From the simulation results it can be seen that when increasing of the gate oxide thickness from $5 \mathrm{~nm}$ to $50 \mathrm{~nm}$, the generation frequency of the ring oscillator decreases from $160 \mathrm{MHz}$ to $32.7 \mathrm{MHz}$ as a result of a 


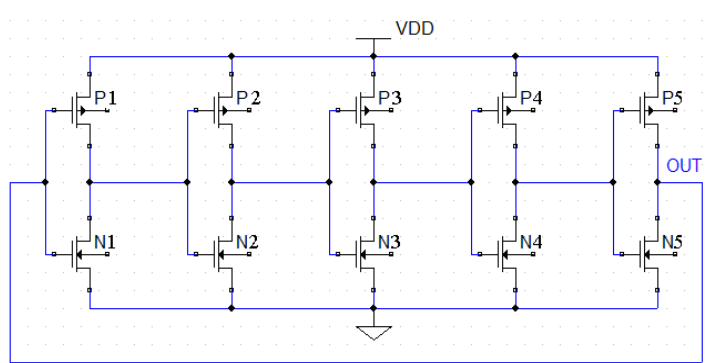

a)

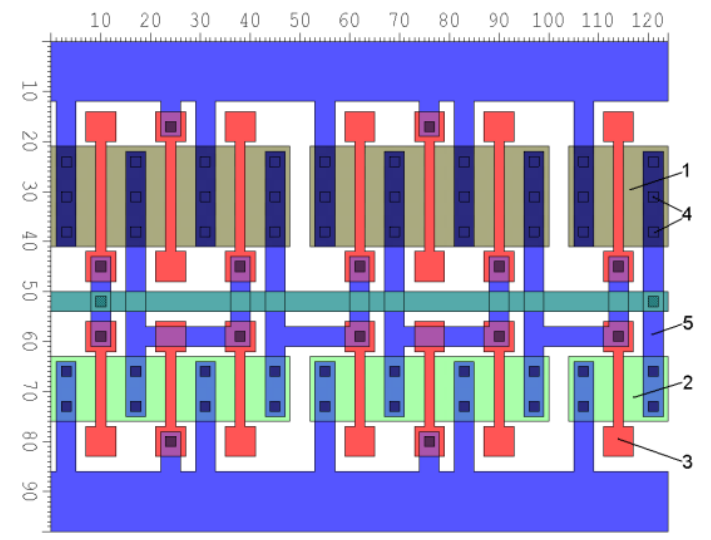

б)

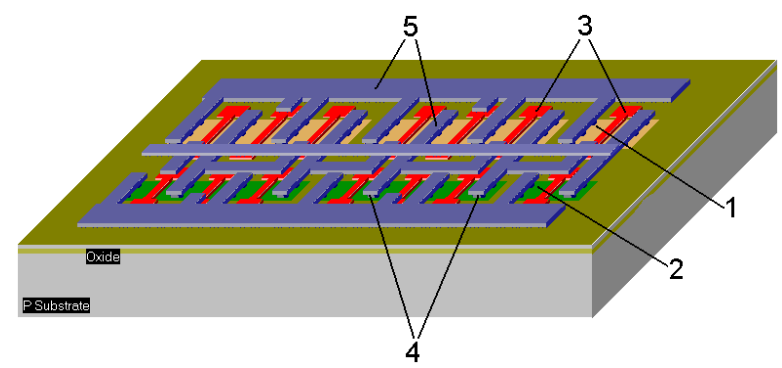

c)

Fig. 1. Electric circuit (a), topology (b) and it three-dimensional image (c) for five-cascading ring oscillator realized on the matrix cell: 1,2 - source-drain regions of the $\mathrm{p}$ - and n-channel of SOI CMOS transistors respectively;

3 - polysilicon gates of $\mathrm{p}$ - and n-channel of SOI CMOS-transistors; 4 - contacts; 5 - interlayer metallization contacts

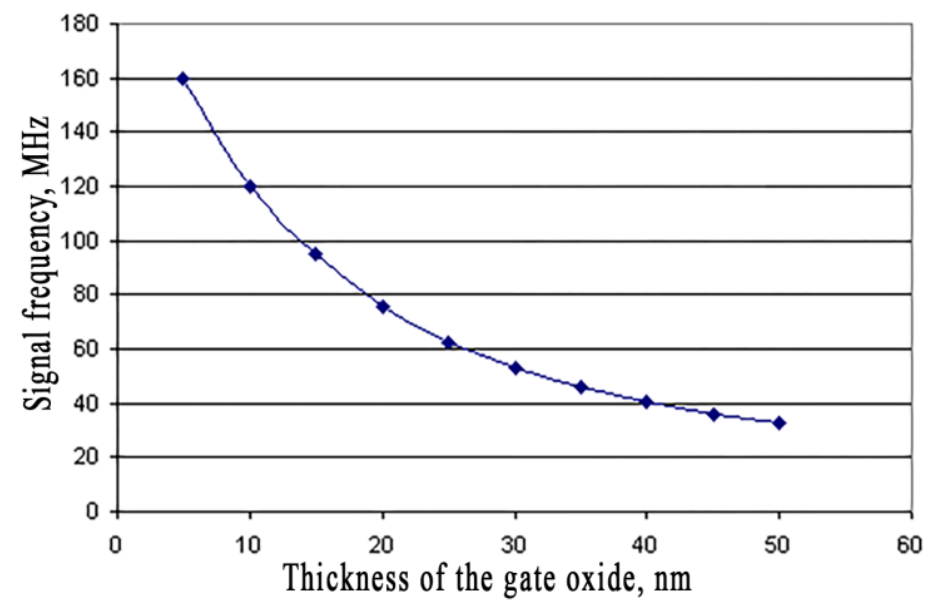

Fig. 2. Dependence of the frequency of the ring oscillator from the thickness of the gate oxide.

Table 1

The dependence of frequency and power consumption from cascade numbers

\begin{tabular}{|c|c|c|}
\hline $\begin{array}{c}\text { Number of } \\
\text { cascades }\end{array}$ & $\begin{array}{c}\text { Frequency, } \\
\mathrm{MHz}\end{array}$ & $\begin{array}{c}\text { Power } \\
\text { consumption, } \mathrm{mW}\end{array}$ \\
\hline 3 & 300.00 & 3.025 \\
\hline 5 & 170.00 & 3.149 \\
\hline 7 & 120.00 & 3.229 \\
\hline 9 & 94.05 & 3.350 \\
\hline 11 & 76.88 & 3.483 \\
\hline 13 & 65.02 & 3.644 \\
\hline 15 & 56.30 & 3.790 \\
\hline
\end{tabular}

decrease in the switching speed of the SOI CMOStransistors. To evaluate the dependence of the number of cascades on the operating frequency, also simulated ring oscillators containing from three to fifteen sequentially connected inverters [3, 4]. The simulation results of frequency and energy characteristics of ring oscillators are given in Table. 1.

The dependence of the frequency of generated signals and power consumption on the number of inverters is shown in Fig. 3

As can be seen from Tab. 1 and Fig. 3, at increases of the ring oscillator cascades number, the frequency of the generated signal decreases. This is due to the accumulation of delays of individual inverters. In addition, with an increase in the number of inverters 


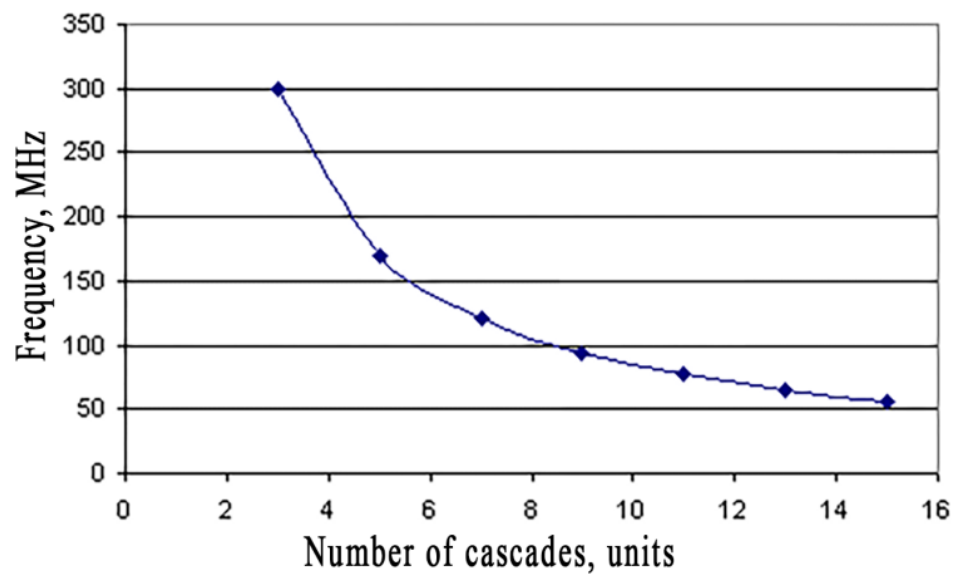

a)

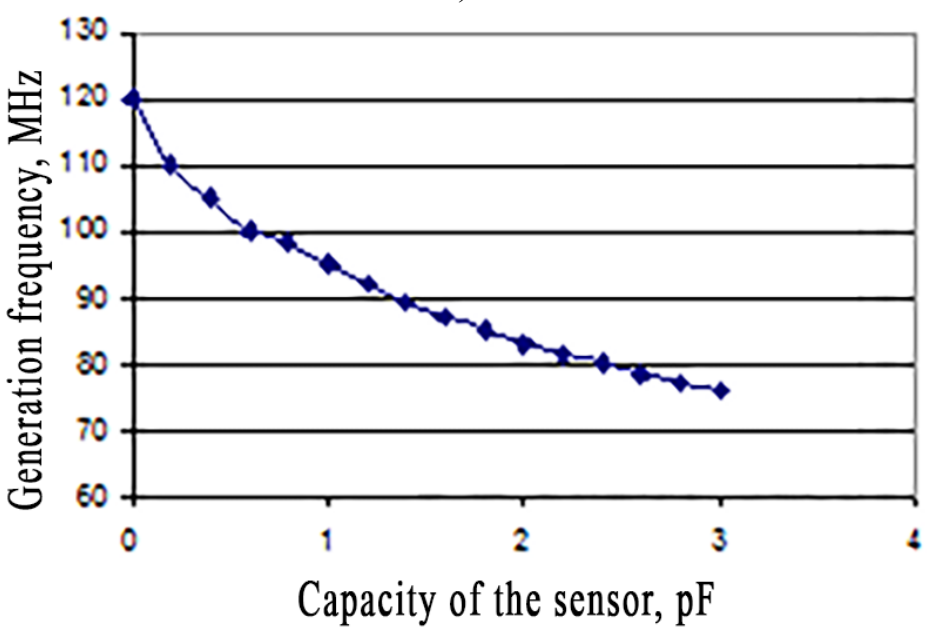

b)

Fig. 3. The dependence of frequency (a) and power consumption (b) from the cascades number of the ring oscillator.

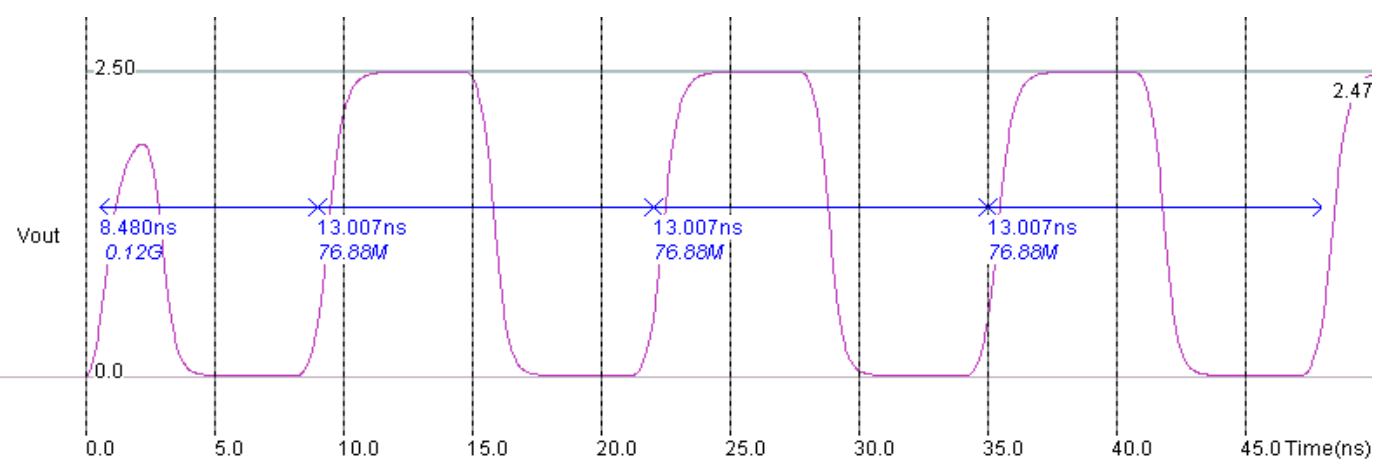

a)

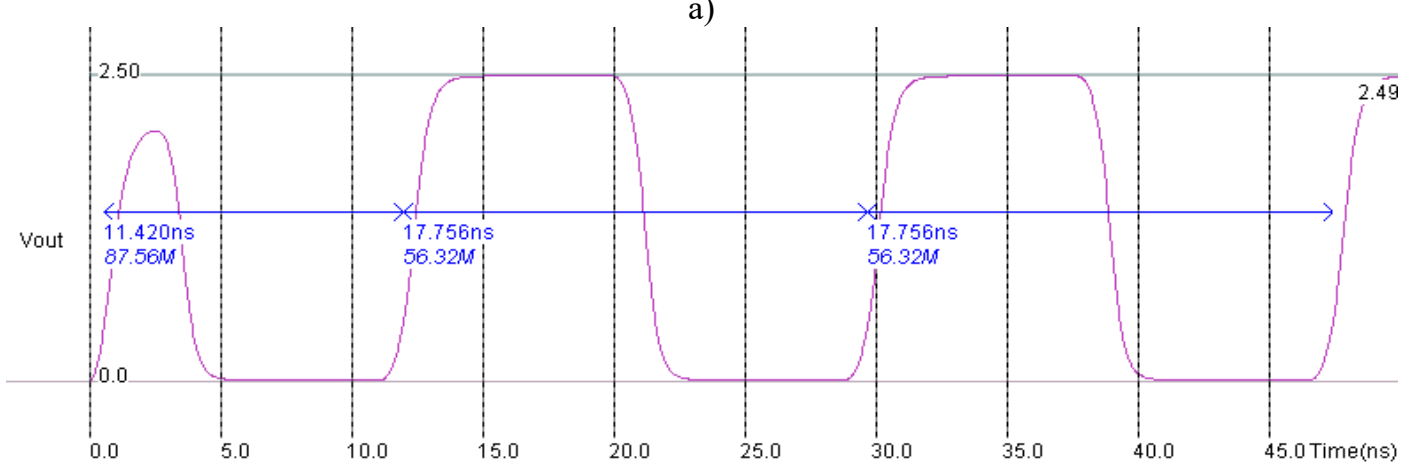

б)

Fig. 4. Results of scheme-topological modeling of the ring oscillator consisting of 11 (a) and 15 (b) cascades. 


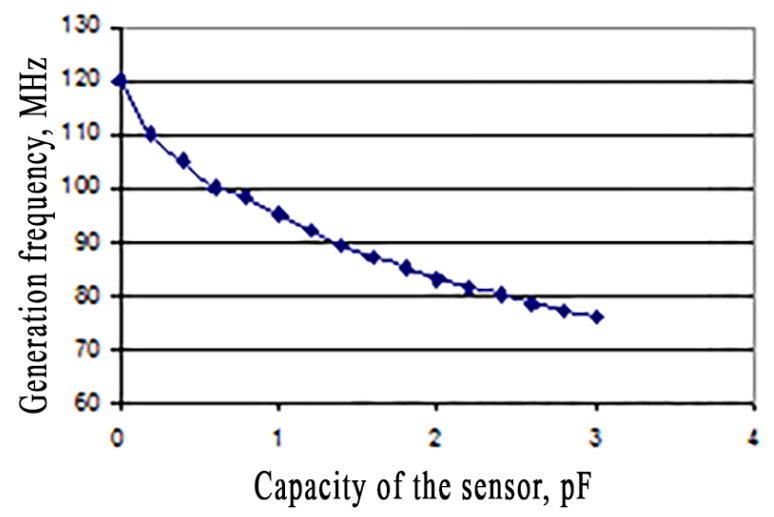

a)

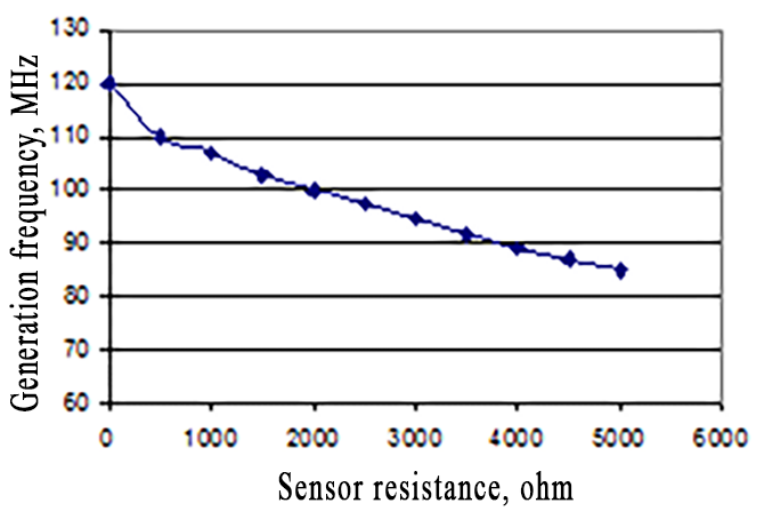

b)

Fig. 5. The frequency dependencies of capacitance (a) and resistance (b) of ring oscillator sensitive elements.

(starting from seven), the generated signal changes its shape from sinusoidal to rectangular pulses, which is explained by the forming properties of the series of connected inverters.

The results of the scheme-topological modeling of the ring oscillator consisting of 11 and 15 cascades are shown in Fig. 4.

As it can be seen from Fig. 4, when the number of cascades increases the frequency of generation decreases.

The ring oscillator diagrams with the number of investigated cascades from 7 to 15 with the specified topological dimensions have limitations on the generation frequency of rectangular pulses in the range from 120 to $300 \mathrm{MHz}$.

\section{Influence of resistive and capasitive sensor elements on frequency characteristics of ring oscillators}

Were investigated the electric circuits of integrated sensors, consisting of 7 cascades of ring oscillators with capacitive and resistive sensing elements which are included in the schemes feedback. At the simulation of these schemes directly from the layouts are used capacitors formed by films of metal- $\mathrm{SiO}_{2}$-metal, metal$\mathrm{SiO}_{2}$-polysilicon, polysilicon- $\mathrm{SiO}_{2}$-silicon-in-isolator and polysilicon resistors and diffusion regions [5].

Variable sensible capacities in the form of moving membranes, beams, and also combed capacitors can be used for experimental samples of the SMSoC, in which the capacity varies from the influence of the physical medium, for example, gas pressure, temperature, light radiation, etc. The results of the scheme-topological modeling of such sensitive elements are shown in Fig. 5 $a, b$. As can be seen from the dependencies, minor changes in sensitive elements cause significant changes in the frequency of the ring oscillator generation.

\section{Conclusions}

The obtained results of the scheme-topological modeling show that the ring oscillators frequency characteristics depends essentially from the number of cascades and the gate oxide thickness of the SOI CMOStransistors. The adding into the ring oscillator of elements sensitive to changes in capacity and/or resistance allows to obtain of highly sensitive sensory circuits in a monolithic integral realization. As shown by the results of simulations, a slight change in the capacity and/or resistance of a sensitive element in the circuit with the ring oscillator results in a significant change in the generation frequency. For example, when capacitance changes from $1 \mathrm{pF}$ to $2 \mathrm{pF}$, the generation frequency changes from $95 \mathrm{MHz}$ to $83 \mathrm{MHz}$, which is approximately $10 \%$. When changing the resistance of a sensitive element from $1000 \mathrm{Ohms}$ to $1500 \mathrm{Ohms}$, the generation frequency changes from $108 \mathrm{MHz}$ to $102 \mathrm{MHz}$.

The simulation results can be used in the SMSoC design for example, for sensors of pressure, temperature and photosensitive elements for non-invasive glucometers and other devices with the SOI-structures.

Kotyk M.V. - assistant of the department of computer engineering and electronics;

Dovgyi $\boldsymbol{V} . \boldsymbol{V}$. - Ph.D., senior engineer;

Kogut I.T. - Professor, Ph.D., Head of the Department of Computer Engineering and Electronics;

Holota V.I. - Associate Professor, Ph.D., Department of Computer Engineering and Electronics.

[1] E. Sicard, S. Delmas Bendhia, Brooks/Cole Publishing Company 737, (2003).

[2] I. T. Kogut, V. I. Holota, A. A. Druzhinin, V. V. Dovhij, Journal of Nano Research (Switzerland) 39, 228 (2015).

[3] V. Dovhij, V. Holota, I. Kogut, Architecture development and elements simulation of analytical microsystemon-chip with "silicon-on-insulator" structures. Proceedings of the 13th International Conference “TCSET'2016” (Lviv-Slavske, 2016). 368. 
[4] A. Druzhinin, Y. Khoverko, V. Dovhij, I. Kogut, V. Holota, Electrical and layouts simulation of analytical microsystem-on-chip elements for high frequence and low temperature applications. UkrMiCo'2016 (Kyiv, 2016). P. 29.

[5] Web-source: http://www.microwind.org.

М.В. Котик, В.В. Довгий, І.Т. Когут, В.І. Голота

\section{Схемотопологічне моделювання КНІ КМОН кільцевих генераторів для сенсорних мікросистем-на-кристалі}

ДВНЗ «Прикарпатський начіональний університет ім. В. Стефаника», вул. Шевченка, 57, м. Івано-Франківськ, 76018, Україна, e-mail: mishanyakit@ gmail.com

В статті наведено результати досліджень частотних та енергетичних характеристик кільцевих генераторів на основі «кремній-на-ізоляторі» КМОН транзисторних структур в залежності від їх схемотехнічної та конструктивно-технологічної реалізації, проектування і моделювання схем первинного перетворення інформації від інтегральних чутливих елементів для сенсорних мікросистем-на-кристалі.

Ключові слова: кремній-на-ізоляторі; кільцевий генератор; чутливий елемент; сенсорна мікросистема-на-кристалі. 